\title{
COMPARING THE POLITICAL TRUST AND CIVIC POLITICAL CULTURE OF DEMOCRACY OR AUTHORITARIAN IN ASIAN COUNTRIES
}

\author{
Hsiu-Wen Yang ${ }^{* 1}$ 四 (iD \\ ${ }^{* 1}$ Ph. D. Candidates, PhD Program of Political Economy, Department of Political Science, National \\ Cheng Kung University, Taiwan
}

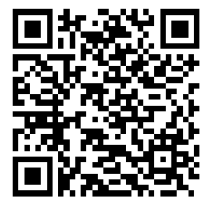

DOI: https://doi.org/10.29121/granthaalayah.v9.i2.2021.3491

Article Type: Research Article

Article Citation: Hsiu-Wen Yang. (2021). COMPARING THE POLITICAL TRUST AND CIVIC

POLITICAL CULTURE OF

DEMOCRACY OR AUTHORITARIAN

IN ASIAN COUNTRIES. International Journal of Research -

GRANTHAALAYAH, 9(2), 320-333. https://doi.org/10.29121/granthaa layah.v9.i2.2021.3491

Received Date: 29 January 2021

Accepted Date: 28 February 2021

Keywords:

Political Trust

Citizen Classification

Cultural Values

Asian Barometer Survey

\section{ABSTRACT}

The political trust of the people is essential for the consolidation of the regime, but it has not been discussed whether the democratic or authoritarian system is more consolidated. This article uses the Asian Democracy Dynamics Survey of 2010 to divide 11 countries into the system of democracy, excessive democracy and autocracy, and autocracy according to the Polity IV index. It will test the people's political trust in these three different political systems, and try to explain the differences from the "cultural perspective" and "citizen classification." The cultural perspective is divided into authoritarianism, traditionalism, collectivism, and Confucian which belongs to the specific political culture in Asia. This paper created the concept of "accepted and rejected" citizenship. Studies have found that the more authoritarian the country, the higher the trust of the people, and it's not easy to change the original regime. In addition to the traditional view, those who do hold culturally authoritative, collective, and Confucian views have high political trust and trust the government to take full responsibility. People have a higher degree of trust in their government, which is the hidden reason that may cause the authoritarian or transitional regime to fail to transform into a democratic regime.

\section{INTRODUCTION}

Whether democracy can be consolidated has always been an important. The stability or change of a country's political system depends on the support of the people of the country. As for whether to support the political system, it is related to the people's "political trust", because trust in the government can also make the system survive. It is necessary to discuss the relationship between political trust and the democratic system.

Regarding the high and low levels of political trust, the influence on the consolidation of the political system is divided into two schools.

Hetherington believes that when trust is too high, it may not be conducive to the operation of democracy. The people may unconsciously trust the government without supervision, and the government does not need to respond to the people's demands and generate dictatorship [10].

However, the reduction of political trust may endanger the continuous operation of the political system. People do not trust the government and therefore desire to overthrow the government. Democracy cannot be consolidated [2]

(C) 2021 The Author(s). This is an open access article distributed under the terms of the Creative Commons Attribution License, which permits unrestricted use, distribution, and reproduction in any medium, provided the original author and source are credited. 


\section{Hsiu-Wen Yang}

Comparing people's political trust from four countries in East Asia, including Japan, Taiwan, South Korea, and China, we found that there are differences between the four countries. Taiwanese people have the lowest political trust and Chinese people have the highest political trust. However, it is difficult to directly judge whether Taiwan, which has a low degree of trust, does have a crisis of democratic survival, or whether it is democratically strong [14].

It means that people do not supervise the government, and they strongly trust the government. In this way, authoritarian government can stabilize non-democratic regimes. According to Polity IV's evaluation of the four East Asian countries, except for China as an autocratic country, the rest are all democracies. The polity score of the Polity IV report in 2012: China is -7, Japan is 10, Taiwan is 10, South Keara is 8 [18]. The past literature did not discuss the relationship between different political regimes and people's trust.

Therefore, this article wants to explore, when non-democratic regimes are included in the study, what is the relationship between regimes and trust?

Political science is used to explain political trust in terms of "institutional approach" and "cultural approach" [19]. The institutional approach used political trust as an immediate performance evaluation of the political system, such as the economic performance of the administrative authority [4], [5]. And whether there is political performance such as bribery, corruption, election fairness, government transparency, etc [3], [27], [23]. Moreover, social performance such as housing, health, employment [26].

Another cultural approach is based on authoritative cultural viewpoints, citizen classification, traditional cultural viewpoints, social capital viewpoints, materialism, Confucian culture, or communism. The direction varies according to cultural differences in different countries [21], [8], [27], [15], [17], [13], [14], [7]. And this article will take the cultural approach to analysis, comprehensively compare the differences between democratic and nondemocratic regimes as the overall political culture segmentation, and design the classification indicators of individual citizenship, and compare the data of Asian countries.

The research questions of this article are as follows: Under the three classifications of political systems of democratic countries, excessively democratic and authoritarian countries, and authoritarian countries, what are the differences in political trust among the people of different countries? And trying to explain the difference between "cultural perspective" and "citizen classification"; cultural perspective is divided into authoritarianism, traditionalism, collectivism, and Confucianism, and citizen classifications are divided into "accepted and objected". In an attempt to explore the gap in individual political trust from the three cultural values and classifications of citizens, we can also further understand whether the different classifications of citizens in these Asian countries belong to dissident citizens with critical thinking, or citizens who obey the authority of the state.

\section{LITERATURE REVIEW}

The definition and operationalization of the term political trust do not have the same argument. Therefore, when analyzing "political trust", this article must first locate the term.

Political trust refers to whether the people can believe that "the political system will avoid harming people's rights and interests, and consider the interests of the people as much as possible [20]. Or it is defined as "the consistency between the results of government administration and the expectations of the people as recognized by the people" [11].

The above definitions all take the public as the starting point and regard a kind of "subjective evaluation." It also shows that how to measure the subjective evaluation of the people is very important.

Why is there a difference in trust? Political science often uses " cultural approach" and "system approach" to explain political trust. It believes that, compared with the latter, the former emphasizes perceptual elements and long-term personal value changes, that is, social trust or social capital. This school believes that the public's trust in politicians or institutions is only an extension of social trust; the institution approach or rational choices think political trust is regarded as endogenous and generated by short-term government performance, and will not have serious consequences for the maintenance of the overall system. Government performance judgments are based on economic performance, political corruption, and political process fairness and transparency [25].

The study has used a multi-level model to analyze political trust from an institutional approach. It found that "the individual's performance in the system" interrelated with "political trust", but this situation would moderate by differences in the "political competition and regime". The link between "evaluation" and "political trust" has been partially confirmed. The effect is mainly in economic and political evaluation, showing that the more intense a 
Comparing the Political Trust and Civic Political Culture of Democracy or Authoritarian in Asian Countries

country's political competition, the lower the people's political trust will occur in a country with a democratic system [28].

However, lack of the cultural approach in previous articles. Therefore, this paper will try to discuss the influence of "cultural approach" on political trust.

Political and cultural research focuses on the theoretical verification of the overall and social level, and explores the people's sense of trust in political institutions and systems, and is suitable for transnational comparative research.

This article believes that this kind of cultural approach is mainly divided into two categories: people's values under different cultures, and classifications of citizens. These themes are all influenced by the "long-term" national background, which establishes different cultural customs in different countries. Instead of the so-called "short-term" performance evaluation of the institutional approach.

When discussing the "People's Cultural View" in the context of each country alone, according to the 2006 Asian Democratic Dynamics Survey to discuss the political trust of six Asian countries based on traditionalism, authoritarianism, and post-materialism. The positive relationship between traditionalism and political trust only occurs in Taiwan, while authoritarianism has an impact in Hong Kong and South Korea, but not in China, Singapore, Taiwan, and Japan, and post-materialism does not affect political trust [27].

When compared the trust of Hong Kong and Taiwan. Wong, Hsiao and Wan pointed out that Hong Kong people highly trust the government and the judiciary, while the legislature has relatively low trust; Both show low trust in different fields such as institutional factors (government performance evaluation, life satisfaction, democratic rights) and cultural factors (interpersonal trust, post-materialism, traditionalism)[26].

The political trust measurement method is based on the trust of seven political organizations as the overall political trust of the country, and the institutional variables are "evaluation of the current overall economic situation of the country's economy, evaluation of the current state of the democratic system, and evaluation of the current state of local government corruption."

The cultural variables are based on "trust to the majority of people in society, political authoritarian values", and individual background variables are considered separately. The article believes that the above variables can be reflected; and through the Freedom House, the "democratic system" of various countries Classification (Freedom House), found that Japan and South Korea, which belong to the old or emerging democracies, compare with other democratic countries Mongolia, Thailand, the Philippines, Taiwan, or semi-democracy. There are certain differences in the political trust of these countries. Among them, non-democratic countries The Chinese people have a high degree of political trust, which confirms the influence of institutional channels on political trust, while social trust only affects political trust in some countries.

In addition to the above-mentioned authoritative and traditional cultural approaches, Chen and Yang cited the research of Inglehart and Baker and believed that when discussing the authoritative system, the Communist Party culture and Confucian culture should be included. "Collectivist values" of values [7].

The three values of authority, tradition and collective are often discussed in the literature to influence individual values. When the overall political culture affects individual citizens, the political culture of citizens must be discussed.

While people's "liberal and democratic values" have a negative effect on the trust and general trust of the central government, while "traditional social values" have a positive effect [15].

Post-materialism is relative to materialism. After long-term economic development and social stability, people have shifted from the values of material satisfaction and security needs to emphasize personal autonomy and multiple values [16]. Traditionalism is a kind of relying on traditional cultural values, emphasizing the maintenance of the existing class order, and collectivism is willing to sacrifice individual interests to achieve social harmony [24]. People with authoritarianism believe that the country must have a strong leader who will take everyone to overcome difficulties, and that individuals are willing to surrender and worship authoritarian. Based on the data of eight Asian countries surveyed by ABS, the impact of institutional and cultural perspectives on political trust is discussed. The cultural perspective includes both "social trust" and "people's cultural outlook [17]."

Norris looked for possible reasons for the depressed political trust in Western countries since the 1960s and proposed "critical citizens". They are a group of "ideologically supportive of democratic systems, but actually criticize the current state of democratic operation." This specific distrust means that the people, on the basis of supporting the democratic system, hold stricter standards and critical attitudes towards the policies of the ruling authorities. Therefore, this "critical" civic attitude is not only ineffective. It will jeopardize democracy and become an optimal 
driving force that takes into account the output of policies in a democratic system. Political distrust is not necessarily a completely negative meaning to the democratic system [21], [22].

At the same time, Dalton linked the modernization theory and argued that, driven by economic development, distrust of the ruling authority is due to the tendency to increase the effect of "self-expression value", which generates a high degree of critical consciousness. The above two arguments are Western democracies. An explanation for the long-term decline in trust [8]. The so-called "citizen classification" in political culture changes between political trust and the trust of political regimes.

Huang uses Taiwan as an example. This article uses empirical data after the 2012 presidential election. At that time, Taiwan was filled with distrust of President Ma Ying-jeou. The study established that "critical citizenship" applies to Taiwanese people's political trust and found that the political trust of "democratic critics" is lower than that of "democratic satisfied people" and "democratic subjects," and "democratic alienators " do not trust the ruling authorities [14]. The critical classifications of citizens discussed above are mainly aimed at the relationship between political support and personal trust in democratic countries.

However, non-democratic countries must also have a certain degree of support for their own "political system", which may also affect personal trust. Since "democratic systems" have "critical" citizens, then non-democratic systems must have obedience is it an " accepted" citizen of an authoritative government? This article will also make a cross-border comparison to find out whether the classifications of citizens are prominently present in different national polities.

From the above, we can see that the institutional approach and cultural approach have their own supporting arguments, and each has explanatory power that can strengthen mutual trust in politics.

Therefore, the impact of cultural approaches on individuals is long-term, unlike the short-term performance evaluation of the system. Therefore, this paper discusses trust again through cultural approaches and incorporates institutional factors and citizen classifications to measure.

\section{DATA}

This article adopts the questionnaire survey research method and uses the third wave of "Asian Barometer Survey" data. The implementation period is from 2010 to 2012. The sample countries are Japan, South Korea, China, Taiwan, Mongolia, Thailand, Singapore, Vietnam, Indonesia, Malaysia and Cambodia. This information is aimed at simultaneous cross-border interviews in Asia, and long-term tracking of personal political attitudes, values and behavioral changes can be called authoritative survey research [9].

\section{RESEARCH STRUCTURE}

Political trust is a dependent variable. Citizen classification, authoritarianism, traditionalism, collectivism, Confucian, personal background, etc. are independent variables. The measurement index of citizen classification is the focus of this article. The design of this indicator is presented in the next section; the above variables, the so-called cultural approach to thinking about the impact on political trust, discussing cross-border and cross-political comparisons.

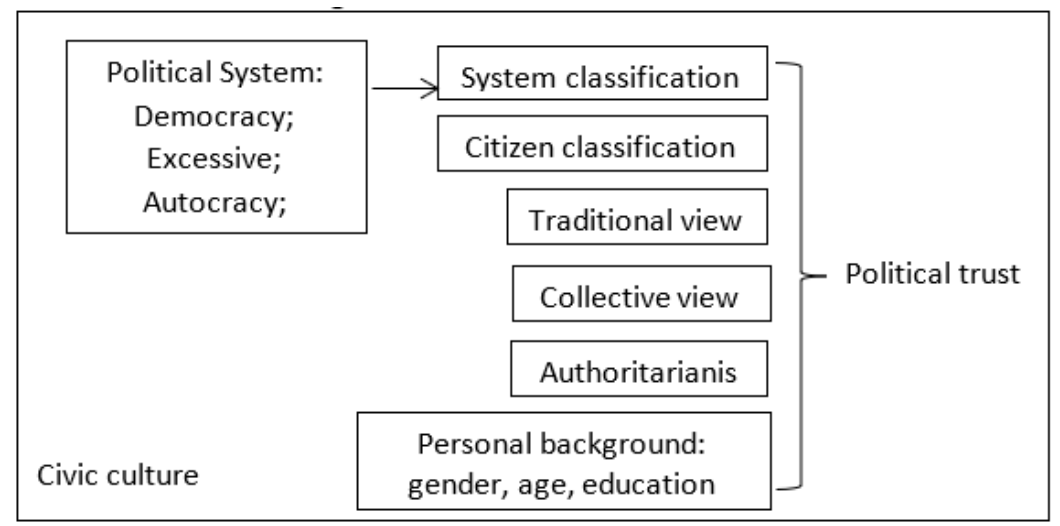

Figure 1: Research Architecture 


\section{MEASUREMENT}

According to the research questions and variables in this article, the measurement question is proposed, which is divided into five parts: political trust, citizen classification, authority view, traditional view, collective view, system classification, and personal background.

This article directly adopts the political trust in the government of a single topic: "You can generally trust the people who run our government to do what is right.." And four of citizen classifications: it is composed of two questions of system support and satisfaction. System classification: The people of 11 countries will be scored according to the Polity IV, 1 point for the autocratic system, 2 points for the democratic and authoritarian system, and 3 points for the democratic system.

The measurement question classifications of various cultural viewpoints are more complicated. Different questions have been changed or deleted according to the ABS in different periods, or changed according to the research questions of scholars. Wong, Wan and Hsiao adopted the 2006 version of ABS, and only measured a single question against traditionalism[26], [27].

In order to compare 2002 and 2011, Chen and Yang as well as research on Confucianism and Communist Party thought as the theme, disassembled traditionalism multi-topics into traditional and collective views, but there are still five questions for measuring traditional views. The question group consists of only 1 is selected as a representative [7].

Chang, $\mathrm{Wu}$ and Weatherall based on the five core Confucian views for constituting measurement questions which are hierarchical collectivism, paternalistic meritocracy, interpersonal reciprocity and accommodation, communal interest and harmony, and Confucian familism [1].

Therefore, this article sets up measurement questions according to the authoritarianism, traditionalism, and collectivism used in the creation of individual documents. For complete questions, please refer to Appendix A. In order to establish the concept of composition, the study first takes confirmatory factor analysis (CFA), and divides the question group into three concepts. The descriptive statistics of each variable are shown in Table 1.

Table 1: Descriptive Statistics

\begin{tabular}{|c|c|c|c|c|}
\hline Variable name & Number of samples & Average & Minimum & Maximum \\
\hline government support & 14671 & 1.65 & 1 & 2 \\
\hline government satisfaction & 14671 & 1.72 & 1 & 2 \\
\hline citizen classification & 14671 & 2.22 & 1 & 4 \\
\hline authoritarianism & 11449 & 0.028 & -3.203 & 3.128 \\
\hline traditional view & 12461 & 0.006 & -2.549 & 2.393 \\
\hline collective view & 13277 & 0.194 & -2.202 & 4.989 \\
\hline Confucianism & 13649 & 0.881 & -2.225 & 3.871 \\
\hline gender & 14660 & 0.494 & 0 & 1 \\
\hline age & 14659 & 2.780 & 1 & 5 \\
\hline education level & 14627 & 6.01 & 1 & 10 \\
\hline Political trust & 14392 & 2.67 & 1 & 4 \\
\hline
\end{tabular}

\section{RESULTS AND DISCUSSIONS}

We first discuss the theoretical framework of citizen classifications, and then analyze the classifications of citizens of various countries with empirical data. Finally, the study would discuss whether the traditional and authoritative civic cultures and the classifications of citizens of various countries cause the level of political trust or not.

\section{Different citizen classifications}

The concept of civic classification is formed by Huang with "democratic satisfaction" and "democratic support". Democracy satisfaction is divided into two standards, "satisfied" and "dissatisfied", which represent the positive and negative evaluation of the democratic system by the people. The degree of democratic support is defined as "absolute 
support" and "incomplete support", showing that the people have unconditional support or limited support and opposition to a democratic government, and they are divided into "democratic satisfaction", "democratic subjects", "democratic critics", and "democratic alienators," please refer to Table 2 [12].

Table 2: Citizen Classification

\begin{tabular}{|c|c|c|c|}
\hline & & \multicolumn{2}{|c|}{ democratic support } \\
\hline & & incomplete support & absolute support \\
\hline \multirow[t]{2}{*}{ democratic satisfaction } & satisfied & $\begin{array}{c}\text { democratic subjects } \\
\text { (highest) }\end{array}$ & $\begin{array}{c}\text { democratic satisfaction } \\
\text { (higher) }\end{array}$ \\
\hline & dissatisfied & $\begin{array}{l}\text { democratic alienators } \\
\text { (Lower) }\end{array}$ & $\begin{array}{c}\text { democratic critics } \\
\text { (lowest) }\end{array}$ \\
\hline
\end{tabular}

Note: Author adapted from [12].

According to Huang classification " democratic satisfaction" referred to people who support democracy unconditionally emotionally, and also express satisfaction with the operation of democracy in evaluation. They all positively evaluate the democratic system and provide the legitimacy and support for the operation of the system [14].

"Democratic critics" referred to unreserved support for democracy but dissatisfaction with the current state of democratic operations. They are the so-called "critical citizens". They have become the critics and supervisors of democratic operations. This classification of political trust should be lower than those of democratic satisfaction and subjects. The above-mentioned two kinds of people bring positive significance to democracy.

"Democratic subjects" lack absolute democratic desires, are satisfied with the status quo of the system, are loyal supporters of the authorities, will not bring harm to democracy, and have a high degree of political trust.

"Democratic alienators " have no absolute desire for democracy. The plot of dissatisfaction with the system is due to the failure of the party they support in the election, which greatly reduces their positive evaluation of the democratic system and has low political trust. Different from critics with low trust, they are the crisis of the consolidation of democracy and they do not trust the legitimacy of democratic politics.

In order to explore which classification of citizens the people of various countries belong to? The author assumes that a certain proportion of citizens in a democratic government are critical citizens, as stated in the research. Relatively speaking, a majority of citizens in a non-democratic government (authoritarian government) are democratic subjects.

The sample selected in Huang article is not a single country and belongs to a democratic regime. Instead, it uses a cross-country and cross-political model to explore the applicability of the theory, so Table 3 is changed.

According to the large-scale ABS survey data, the so-called "democratic" survey is also the first focus. When interviewing countries in Asia, the relevant democratic issues in countries with the "non-democratic" system were not specifically distinguished. Most of the previous articles, when cutting into the study of non-democratic countries, mainly discussed "what do they think of the legitimacy of democracy", but rarely directly discuss which classification of citizen they belong to.

Therefore, this article attempts to discuss together the differences in political trust caused by the classifications of citizens in the three systems (democracy, excessive, democracy and autocracy, and autocracy).

The author renamed "Democracy Support" and "Democracy Satisfaction" to "System Support" and "System Satisfaction". The reason for this change is that people in non-democratic countries are also targeting the "Democracy" questionnaire.

Reply to the question, but this kind of subjective response to the system performance or support of their own country, compared to the objective Polity IV sub-indicators, they do not achieve the indicators of the so-called "democratic" regime, so they cannot be called "democratic support "and "democratic satisfaction." It can only be said to be subjective ratings of one's own political system.

In addition, the government support part is further divided into three classifications of government: "democracy," " excessive democracy and autocracy," and "autocracy." There are 12 classifications that interact with government satisfaction. Classification 1, 5, and 9 citizens tend to "accept".

Although they do not fully support the country's regime, they are still satisfied with the current state of affairs. They obey the current state of the country's regime model. Classification 4, 8, and 12 citizens are more inclined to 
"dissent" and absolutely support China's political system, but in fact it is not satisfied with the operating conditions, and continues to criticize it, hoping to improve the operating conditions. As for the $2,3,6,7,10,11$ citizens, they are in the middle, but those who are satisfied tend to obey and accept. The alienators tend to express dissent.

Table 3: Citizen Classification with Political System

\begin{tabular}{|c|c|c|c|c|c|c|c|}
\hline & \multicolumn{6}{|c|}{ System Support } \\
\hline & & \multicolumn{2}{|c|}{ democracy } & \multicolumn{2}{|c|}{$\begin{array}{c}\text { excessive } \\
\text { democracy and autocracy }\end{array}$} & \multicolumn{2}{|c|}{ autocracy } \\
\hline & & $\begin{array}{l}\text { incomplete } \\
\text { support }\end{array}$ & $\begin{array}{l}\text { absolute } \\
\text { support }\end{array}$ & $\begin{array}{l}\text { incomplete } \\
\text { support }\end{array}$ & $\begin{array}{c}\text { absolute } \\
\text { support }\end{array}$ & $\begin{array}{l}\text { incomplete } \\
\text { support }\end{array}$ & $\begin{array}{l}\text { absolute } \\
\text { support }\end{array}$ \\
\hline \multirow{2}{*}{ 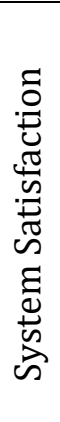 } & 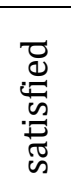 & $\begin{array}{c}\text { subjects } \\
\text { (1) }\end{array}$ & $\begin{array}{c}\text { satisfaction } \\
\text { (2) }\end{array}$ & $\begin{array}{l}\text { subjects } \\
\text { (5) }\end{array}$ & $\begin{array}{c}\text { satisfaction } \\
\text { (7) }\end{array}$ & $\begin{array}{c}\text { subjects } \\
\text { (9) }\end{array}$ & $\begin{array}{c}\text { satisfaction } \\
\text { (11) }\end{array}$ \\
\hline & 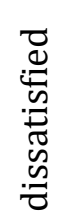 & alienators (3) & $\begin{array}{l}\text { critics } \\
(4)\end{array}$ & $\begin{array}{l}\text { alienators } \\
\text { (6) }\end{array}$ & $\begin{array}{l}\text { critics } \\
(8)\end{array}$ & alienators (10) & $\begin{array}{l}\text { critics } \\
(12)\end{array}$ \\
\hline
\end{tabular}

Source: by authors

The coding is to classify each country by degree, recode and name the variable as "citizen classification". The larger the number, the more accepted citizens are favored, and the smaller the number, the more objected citizens. The regime classification standard is based on Polity IV, please refer to Table 3 and Figure 2.

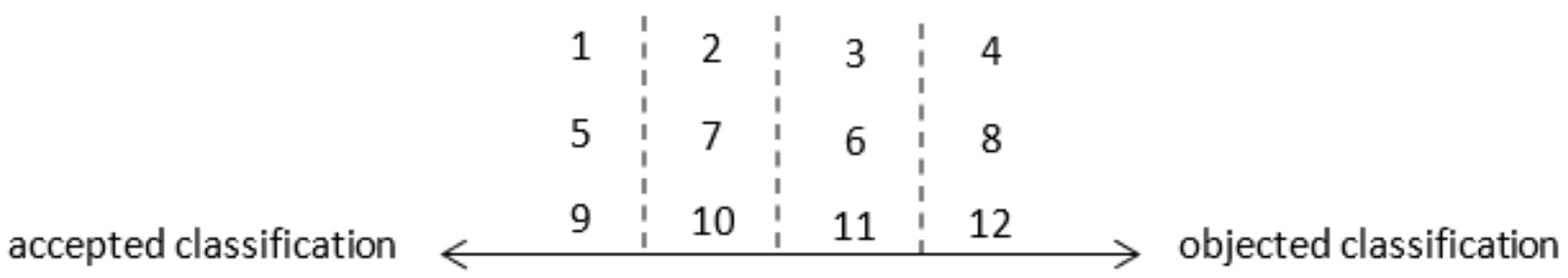

Figure 2: Continuous Variable of the Citizen Classification

The empirical data (Table 4) shows that in a democratic regime, there are more critics, and the proportion of submissive citizens in an authoritarian regime is relatively large, confirming the research hypothesis of this article.

In terms of the proportion of critics who account for the country's citizens, democracies have the highest proportions compared to other political systems, especially in Indonesia, Japan, South Korea, and Mongolia. Countries in the transitional period between democratic government and authoritarian government have the highest proportion of citizens. Critical citizens or subjects submissive citizens on both sides of the spectrum are not particularly biased.

As for non-democratic regimes, they are most satisfied with the democratic system of the "own country". The proportion of subjective citizens is higher than that of other countries.

The result of this may be that after a long period of democratization, a change in the classifications of citizens has occurred, and it may not be due to the change in the political system being affected by the classifications of citizens. This argument can be proved by the "transition period from democracy to autocracy." The proportion of critical critics in Cambodia and Thailand is not high.

Therefore, there are indeed differences in the classifications of citizens among countries with different political systems. The focus of this article will be discussed below. This classification of citizens effects of "the people believe that the government can do the right thing".

From the assumption of political trust and polity, the country with the lowest political trust shound have more critical citizens. However, Taiwan's data shows that people's political trust with ranks at the bottom of the 11 
countries, but Taiwan citizens belongs more subjectives than the other democratic countries. Taiwan is a special case with a higher proportion of accepted citizens and a lower degree of trust in the government.

According to Table 5, although the results of this article are similar to the empirical data of Ref. [12] [14] in Taiwan in 2008 and 2012, the results are similar. According to the data in 2008, 22.2\% of the obedient, $31.9 \%$ of the satisfied, 28.1\% of the divorced, and critics 17.9\%; According to data in 2012, 31.0\% are subjects, $41.5 \%$ are satisfied, $12.9 \%$ are alienated, and $15.4 \%$ are critics. He believes that Taiwan applies for a critical citizenship and shows that Taiwan has a stable critical attitude, which is beneficial The democratic system operates. According to the results of this article, although different databases are selected and a single country is used as the research target, the results are similar. However, in terms of cross-country comparisons, the Taiwan case does not seem to belong to "Critical" the comparison of "democratic" countries. However, in terms of cross-country research, when comparing other" democratic" countries, the Taiwan case does not seem to be "critical"(see Table 4).

Table 4: Percentage of the Citizen Classification

\begin{tabular}{|c|c|c|c|c|c|c|}
\hline \multirow[b]{2}{*}{ system classification } & \multirow[b]{2}{*}{ country } & \multicolumn{4}{|c|}{ citizen classification (\%) } & \multirow[b]{2}{*}{$\mathrm{N}$} \\
\hline & & subjects & satisfaction & alienators & critics & \\
\hline \multirow[t]{6}{*}{ autocracy } & Indonesia & 15.1 & 45.6 & 13.6 & 25.8 & 1212 \\
\hline & Korea & 16.3 & 44.8 & 13.8 & $\underline{25.0}$ & 1386 \\
\hline & Japan & 15.8 & 40.6 & 19.9 & $\underline{23.7}$ & 1425 \\
\hline & Mongolia & 21.5 & 26.9 & $\underline{28.6}$ & $\underline{23.0}$ & 1446 \\
\hline & Malaysia & 14.0 & 60.4 & 7.7 & 17.9 & 1414 \\
\hline & Taiwan & $\underline{32.6}$ & 38.0 & 15.1 & 14.3 & 1411 \\
\hline \multirow[t]{2}{*}{ democracy and autocracy } & Cambodia & $\underline{34.0}$ & 48.6 & 7.3 & 10.1 & 1474 \\
\hline & Thailand & 17.1 & $\underline{66.2}$ & 3.8 & 13.0 & 1267 \\
\hline \multirow[t]{4}{*}{ autocracy } & Singapore & $\underline{43.9}$ & 47.7 & 5.4 & 2.9 & 1375 \\
\hline & China & $\underline{25.4}$ & 49.4 & 10.3 & 15.0 & 1178 \\
\hline & Vietnam & 8.7 & $\underline{79.6}$ & 3.2 & 8.5 & 1083 \\
\hline & $A L L$ & $\begin{array}{c}22.6 \\
(3318)\end{array}$ & $\begin{array}{c}49.0 \\
(7187)\end{array}$ & $\begin{array}{c}12.0 \\
(1716)\end{array}$ & $\begin{array}{c}16.4 \\
(2405)\end{array}$ & $\begin{array}{c}14671 \\
(N)\end{array}$ \\
\hline
\end{tabular}

Table 5: Percentage of Taiwan's Citizen in Different Year of the study

\begin{tabular}{|c|c|c|c|c|}
\hline Year and researcher & subjects & satisfaction & alienators & critics \\
\hline 2008 / Huang & $22.2 \%$ & $31.9 \%$ & $28.1 \%$ & $17.9 \%$ \\
\hline $2010 /$ this paper & $32.6 \%$ & $38.0 \%$ & $15.1 \%$ & $14.3 \%$ \\
\hline 2012 / Huang & $31.0 \%$ & $41.5 \%$ & $12.9 \%$ & $15.4 \%$ \\
\hline
\end{tabular}

Next, this article also designed the citizen classification indicator as a continuous observation variable. In order to detect again whether there are significant differences in citizen classifications between countries, this article conducts a statistical one-way-ANOVA, using the Schaffer method and the Post Hoc test, it was found that the P-value of the overall model was less than 0 , which was a significant correlation. The difference in citizen classifications is indeed between countries (see Table 6-ANOVA test for the results)

A comparison of individual countries found that it is also a cluster of democracies. Taiwan's citizen score is 0.42 less than Mongolia's, 0.40 less than Japan, 0.36 less than South Korea, 0.38 less than Indonesia, and 0.18 less than Malaysia. It has once again verified its representativeness in a democracy that the people of Taiwan are significantly more "submissive" than the people of other democratic countries. There is no significant difference in citizenship scores among Mongolia, Japan, South Korea, and Indonesia. Only Malaysia scores lower than Japan's 0.22 and lower than Mongolia's 0.23. And Indonesia is 0.16 lower than Malaysia.

In summary, the scores of citizens of Mongolia, Japan, South Korea, and Indonesia are more consistent. Taiwan is a special case. As for the reason, the information on Taiwan must be independently investigated in further study.

There are still differences in the scores of citizens between Thailand and Cambodia, which are in the middle of the polity, and Cambodia people are like accepting citizens. Most Thailand people are satisfaction types. 
Among the autocratic countries, China and Vietnam are no different. Singapore is more subjects than China's (0.47), but after Vietnam, it belongs to the alienators classification $(0.44)$, which is in the middle of the autocratic country.

Table 6: ANOVA Test

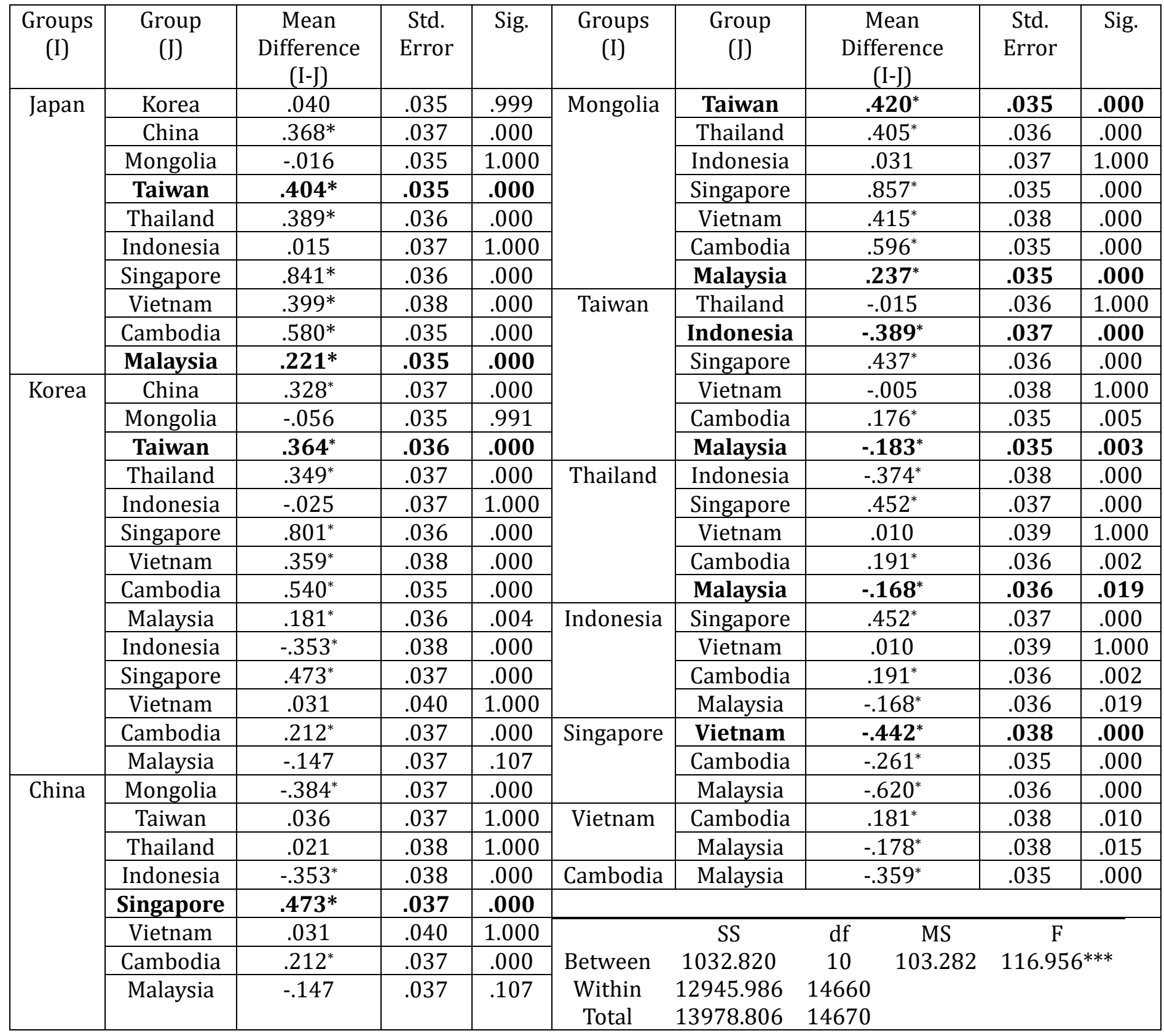

\section{CULTURAL AND CIVIC CLASSIFICATIONS TRUST IN POLITICS}

First of all, the author conducts a chi-square test of political trust and citizenship, and makes a cross-tabulation of the two variables as shown in Table 7. It can be found that only in "political trust disagrees and subjects" $(\mathrm{Z}=-0.8)$, "political trust strongly agrees and subjects" $(\mathrm{Z}=-1.9), "$ political trust strongly and alienators" $(\mathrm{Z}=-1.2)$. The three parts are not significantly related. Although "high political trust and subjects" is no significant, it still closer the standard -1.96 set by the standardized residuals. It can also be said that the two are related. The rest show that political trust and civic classification are related, and the overall model also shows that the two are related. 
Table 7: Cross-table with Citizen Classification and Poloitical Trust

\begin{tabular}{|c|c|c|c|c|c|c|}
\hline & \multicolumn{4}{|c|}{ Political Trust } & \multirow[t]{2}{*}{ Total } \\
\hline & & \multicolumn{2}{|c|}{ strongly disagree disagre } & \multirow{2}{*}{\begin{tabular}{|l|} 
agree \\
1579 \\
\end{tabular}} & \multirow{2}{*}{\begin{tabular}{|c|}
$\begin{array}{c}\text { strongly } \\
\text { agree }\end{array}$ \\
457 \\
\end{tabular}} & \\
\hline \multirow{3}{*}{ subjects } & frequency & 211 & 1014 & & & 3261 \\
\hline & effect frequency & 268.5 & 1040.5 & 1452.4 & 499.6 & 3261.0 \\
\hline & standardized residual & -3.5 & -0.8 & 3.3 & -1.9 & \\
\hline \multirow[t]{3}{*}{ satisfaction } & frequency & 322 & 1952 & 3522 & 1238 & 7034 \\
\hline & effect frequency & 579.2 & 2244.3 & 3132.8 & 1077.7 & 7034.0 \\
\hline & standardized residual & -10.7 & -6.2 & 7.0 & 4.9 & \\
\hline \multirow[t]{3}{*}{ alienators } & frequency & 268 & 691 & 531 & 246 & 1736 \\
\hline & effect frequency & 142.9 & 553.9 & 773.2 & 266.0 & 1736.0 \\
\hline & standardized residual & 10.5 & 5.8 & -8.7 & -1.2 & \\
\hline \multirow[t]{3}{*}{ critics } & frequency & 384 & 935 & 778 & 264 & 2361 \\
\hline & effect frequency & 194.4 & 753.3 & 1051.6 & 361.7 & 2361.0 \\
\hline & standardized residual & 13.6 & 6.6 & -8.4 & -5.1 & \\
\hline \multirow[t]{2}{*}{ Total } & frequency & 1185 & 4592 & 6410 & 2205 & 14392 \\
\hline & effect frequency & 1185.0 & 4592.0 & 6410.0 & 2205.0 & 14392.0 \\
\hline \multicolumn{7}{|c|}{$\begin{array}{l}\text { Pearson's chi-squared }=799.135^{* * *}, \text { Likelihood ratio }=77.585^{* * *}, \\
\text { Cramer's V }=0.136^{* * *}, \text { Contingency correlation }=0.229^{* * *} . \\
\text { Note: The strongly agree means people with the high level of political trust. } \\
{ }^{*} \mathrm{p}<.05 .^{* *} \mathrm{p} .<.01 .{ }^{* * *} \mathrm{p}<.001 .\end{array}$} \\
\hline
\end{tabular}

Therefore, we can see that there is a correlation between the classifications of citizens and trust, and then this two variable is included in the regression of the overall political trust. Comparing the personal background variable: gender, age, education level. Trying to explain the explanatory power of political trust under the cultural approach, the results refer to Table 8 .

In terms of personal background, the higher the education level of the people, the less they trust the government $\left(\beta=-0.058^{* * *}\right)$, but men or women, which does not affect personal political trust. $(\beta=0.014)$ When Yang and Meng discuss trust from an institutional approach, the older they are, the more they trust the government(Yang and Meng 2015). However, after incorporating the factors of culture and civic classification, this article finds that age does not affect personal political trust.

Among the cultural approaches, especially the "political authority view" and "citizen classification" have the greatest impact on personal political trust $(\beta=-0.084)$.

People who tend to be accepted and authoritative tend to trust the government's actions. Relatively speaking, people tend to be objected and democratic value does not trust the government to govern $(\beta=-0.206)$. The more people with a view of political authority, the more they identify with those in power and obey the government's decision-making.

And the more Confucian people emphasize harmony and patriarchy, they also "trust" the government $(\beta=-$ $\left.0.220^{* * *}\right)$. People with a collective view tend to trust the government to govern. Those with personal views are less able to trust the government simply because they have their own opinions $\left(\beta=-0.062^{* * *}\right)$.

The more the classifications of citizens are toward submissives or accepted, the more they "trust" the government. People who trust the government and lean toward the authoritarian system are more likely to trust the government $\left(\beta=-0.065^{* * *}\right)$. Except that the traditional view has nothing to do with political trust, the above results conform to the research hypothesis of this article $(\beta=-0.011)$.

Table 8: The Simple Linear Regression of Political Trust Model

\begin{tabular}{|c|c|c|c|}
\hline \multirow{2}{*}{ Variable } & \multicolumn{2}{|c|}{$\begin{array}{c}\text { Unstandarlized } \\
\text { Coffivient }\end{array}$} & Unstandarlized Coffivient \\
\cline { 2 - 4 } & Beta & $S E$ & Beta \\
\hline citizen classification & $-0.071^{* * *}$ & $(0.007)$ & $-0.084^{* * *}$ \\
\hline Authoritarianism & $-0.172^{* * *}$ & $(0.009)$ & $-0.206^{* * *}$ \\
\hline
\end{tabular}


Comparing the Political Trust and Civic Political Culture of Democracy or Authoritarian in Asian Countries

\begin{tabular}{|c|c|c|c|}
\hline Traditionalism & -0.009 & $(0.008)$ & -0.011 \\
\hline Collectivism & $-0.051^{* * *}$ & $(0.009)$ & $-0.062^{* * *}$ \\
\hline Confucian & $-0.179^{* * *}$ & $(0.010)$ & $-0.220^{* * *}$ \\
\hline Regime type & $-0.027^{* * *}$ & $(0.015)$ & $-0.065^{* * *}$ \\
\hline Gender & 0.027 & $(0.015)$ & 0.014 \\
\hline Age & -0.008 & $(0.006)$ & -0.013 \\
\hline Education & $-0.019^{* * *}$ & $(0.003)$ & $-0.058^{* * *}$ \\
\hline Intercept & $3.102^{* * *}$ & $(0.039)$ & \\
\hline \multicolumn{2}{|c|}{$\mathrm{R}=0.466, \mathrm{R}^{2}=0.217$, adjusted $\mathrm{R}^{2}=0.216, \mathrm{df}=9, \mathrm{~F}=306.614^{* * *}$} \\
\hline
\end{tabular}

Note: Dependent variable is political trust and ${ }^{*} \mathrm{p}<.05{ }^{* *} \mathrm{p} .<.01 .{ }^{* * *} \mathrm{p}<.001$.

\section{CONCLUSIONS AND RECOMMENDATIONS}

Discussing the influence of people's political trust from the cultural approach, coupled with the classification of civic culture, is different from the previous institutional approach and cultural approach to political trust research. Under the political and cultural background of each country, there is a civic political culture that is exclusive to their own country, and the distinction between the classifications of citizens in the political system is generally consistent with the research inference.

This article initially attempts to use cross-sectional and single-year data to discuss the relationship between political trust, culture, and civic classifications. It belongs to the macro-level analysis.

It is suggested that when studying cultural approaches in the future, takes a long-term trend study, and it is more likely to find the trend of high trust to low trust, or low trust to high trust, and the reasons and key points of the change by the case study.

In this way, it is possible to explore whether changes in trust and "inter-system" constraints can be improved from "key points" to avoid conflicting images of democracy and trust. Or, it is possible to break through the limitations of empirical analysis research methods, join the government's political trust, and discuss the dynamics of "mutual trust" between the people and the government. This may also be an important indicator that whether the polities of various countries can survive.

Finally, if the researcher can join the discussion again, the various democratic issues of the people in transitional countries or countries with authoritarian regimes, such as: what is the concept of democracy, and whether they agree with "democratic values", whether democratic values are high or low? The underlying factors may affect why they belong to this classification of citizens and how to generate the effect of high and low political trust.

\section{APPENDICES}

\begin{tabular}{|c|c|}
\hline Variable & Questionnaire \\
\hline Political trust & You can generally trust the people who run our government to do what is right. \\
\hline \multirow[t]{2}{*}{$\begin{array}{c}\text { Citizen } \\
\text { classification }\end{array}$} & $\begin{array}{c}\text { Which of the following statements comes closest to your own opinion? } \\
1 \text { Democracy is always preferable to any other kind of government } \\
2 \text { Under some circumstances, an authoritarian government can be preferable to a } \\
\text { democratic one } \\
3 \text { For people like me, it does not matter whether we have a democratic or a nondemocratic } \\
\text { regime }\end{array}$ \\
\hline & $\begin{array}{c}\text { On the whole, how satisfied or dissatisfied are you with the way democracy works in } \\
\text { [Country]. Are you ...? Very Satisfied, Fairly satisfied, Not at all satisfied. }\end{array}$ \\
\hline Authoritarianism & $\begin{array}{l}\text { 1. I have here other statements. For each statement, would you say you strongly agree, } \\
\text { somewhat agree, somewhat disagree, or strongly disagree? } \\
\text { 2. The government should consult religious authorities when interpreting the laws. } \\
\text { 3. Women should not be involved in politics as much as men. } \\
\text { 4. People with little or no education should have as much say in politics as highly-educated } \\
\text { people. }\end{array}$ \\
\hline
\end{tabular}




\begin{tabular}{|c|c|}
\hline & $\begin{array}{l}\text { 5. The government should decide whether certain ideas should be allowed to be discussed } \\
\text { in society. } \\
\text { 6. Harmony of the community will be disrupted if people organize lots of groups. } \\
\text { 7. When judges decide important cases, they should accept the view of the executive } \\
\text { branch. } \\
\text { 8.If the government is constantly checked [i.e. monitored and supervised] by the } \\
\text { legislature, it cannot possibly accomplish great things. } \\
\text { 9.If people have too many different ways of thinking, society will be chaotic. } \\
\text { 10. When the country is facing a difficult situation, it is ok for the government to disregard } \\
\text { the law in order to deal with the situation. }\end{array}$ \\
\hline Traditionalism & $\begin{array}{l}\text { 1. Please tell me how you feel about the following statements. Would you say you strongly } \\
\text { agree, somewhat agree, somewhat disagree, or strongly disagree? } \\
\text { 2. Even if parents' demands are unreasonable, children still should do what they ask. } \\
\text { 3. When a mother-in-law and a daughter-in-law come into conflict, even if the mother-in- } \\
\text { law is in the wrong, the husband should still persuade his wife to obey his mother. } \\
\text { 4. Being a student, one should not question the authority of their teacher. } \\
\text { 5. Wealth and poverty, success and failure are all determined by fate. } \\
\text { 6. If one could have only one child, it is more preferable to have a boy than a girl. }\end{array}$ \\
\hline Collectivism & $\begin{array}{l}\text { 1. For the sake of the family, the individual should put his personal interests second } \\
\text { 2.When dealing with others, developing a long-term relationship is more important than } \\
\text { securing one's immediate interest. } \\
\text { 3. When dealing with others, one should not only focus on immediate interest but also plan } \\
\text { for future. } \\
\text { 4. In a group, we should avoid open quarrel to preserve the harmony of the group } \\
\text { 5. When dealing with others, one should not be preoccupied with temporary gains and } \\
\text { losses. }\end{array}$ \\
\hline Confucian & $\begin{array}{l}\text { 1. Government leaders are like the head of a family; we should all follow their decisions. } \\
\text { 2. If we have political leaders who are morally upright, we can let them decide everything. } \\
\text { 3. For the sake of national interest, individual interest could be sacrificed. } \\
\text { 4. In a group, we should avoid open quarrel to preserve the harmony of the group } \\
\text { 5. Even if there is some disagreement with others, one should avoid the conflict }\end{array}$ \\
\hline
\end{tabular}

\section{SOURCES OF FUNDING}

This research received no specific grant from any funding agency in the public, commercial, or not-for-profit sectors.

\section{CONFLICT OF INTEREST}

The author have declared that no competing interests exist.

\section{ACKNOWLEDGMENT}

The authors wish to acknowledge grant Asian Barometer Survey from Hu Fu Center for East Asia Democratic Studys that supported this research.

\section{REFERENCES}

[1] Chang, Young-Hee, Jack Junzhi Wu and Mark Weatherall. (2017). "Popular Value Perceptions and Institutional Preference for Democracy in "Confucian" East Asia." Asian perspective 41(3), 347-375.

[2] Chu, Yun-han, Larry Diamond, Doh Chull Shin. (2001). "How People View Democracy: Halting Progress in Korea and Taiwan." Journal of Democracy 12(1), 122-136. 
Comparing the Political Trust and Civic Political Culture of Democracy or Authoritarian in Asian Countries

[3] Chen, Don-Yun. 2009. "Accountability through Transparency: The Foundation of Rebuilding Trust between Government Officials and Citizens under Democratic Governance in Taiwan." Journal of Civil Service 1(2), 132.

[4] Chen, Lu-Huei. (2003). "Political Trust, Government Performance, and the Perspective of Deepening Democracy among the Electorate in Taiwan." The Taiwanese Political Science Review 7(2), 149-188.

[5] Chen, Lu-Huei. (2006). "Political Consequences of Political Trust: The Case of 2004 Legislative Elections in Taiwan." Taiwan Democracy Quarterly 3(2), 39-62.

[6] Chen, Lu-Huei. (2007). "Political Trust in Central and Local Government and Its Effects on Magisterial Elections," Chinese Political Science Review 43, 43-70.

[7] Chen, Lu-Huei and Gui Yang. (2018). "Continuity and Change of Political Orientation among Citizens in Transitional China: An Analysis of Typology." Mainland China Studies 61(3), 1-32.

[8] Dalton, Russell J. (2009). The Good Citizen: How a Younger Generation is Reshaping American Politics. Washington, D.C.: CQ press, 3-6.

[9] $\mathrm{Fu}, \mathrm{Hu}$ and Yun-han Chu. (2012). "Asian Barometer Survey 2010-2012. " Accessed at http://www.eastasia.ipsas.sinica.edu.tw/index-2.html(December 03, 2014).

[10] Hetherington, Marc J. (1998). "The Political Relevance of Trust." American Political Science Review 92(4), 791-808.

[11] Hetherington, Marc J. (2005). Why Trust Matters: Declining Political Trust and the Demise of American Liberalism. Princeton: Princeton University Press.

[12] Huang, Hsin-Hao. (2011). "Constructing a Typology of Popular Attitudes to Democracy: An Analysis after the Second Party Alternation in Taiwan." Journal of Electoral Studies 18(1), 1-34.

[13] Hsung, Ray-May. (2014). "Social Capital and Trust: Reflections on Data from the East Asia Social Capital Survey." Taiwanese Journal of Sociology 54, 1 -30.

[14] Huang, Hsin-Hao. (2014). "The Origins of Political Trust in Taiwan Revisited: A Test of the 'Critical Citizens' Explanation." Taiwan Democracy Quarterly 1(11), 153-193.

[15] Ikeda, Ken'ichi. (2013). "Social and Institutional Trust in East and Southeast." Taiwan Journal of Democracy 9(1), 13-45.

[16] Inglehart, Ronald. (1997). Modernization and Postmodernization: Cultural, Economic, and Political Change in 43 Societies. Princeton, NJ: Princeton University Press.

[17] Ma, De-Yong. (2007). "Institutional and Cultural Factors of Political Trust in Eight Asian Societies. " Comparative Economic \& Social Systems 5, 79-86.

[18] Marshall, Monty G. (2013)." Polity IV: Regime Authority Characteristics and Transitions, 1800-2013." The Center for Systemic Peace. Accessed at https://www.systemicpeace.org/polity/polity4.htm (October 30, 2020)

[19] Mishler, William and Rose Richard. (2001). "What are the origins of political trust?: Testing institutional and cultural theories in post-communist societies." Comparative Political Studies 34(1), 30-62.

[20] Newton, Kenneth. (2007). "Social and Political Trust." In Russell J. Dalton and Hans-Dieter ed, The Oxford Handbook of Political Behavior, Oxford: The Oxford University Press.

[21] Norris, Pippa. (1999). "Introduction: The growth of critical citizens?" In: Norris Pippa, ed., Critical Citizens: Global Support for Democratic Government, Oxford: Oxford University Press.

[22] Norris, Pippa. (2011). Democratic Deficit: Critical Citizens Revisited. New York: Cambridge University Press.

[23] Schumacher, Ingmar. (2013). "Political stability, corruption and trust in politicians." Economic modelling 31, 359-69.

[24] Shi, Tianjian. (2001). "Cultural values and political trust: A comparison of the People's Republic of China and Taiwan. " Comparative Politics 33(4), 401-419.

[25] Wang, Jong-Tian. (2010). "When Social Trust Meets Political Trust: The Integration and Test of Theories of Political Culture." Taiwan Democracy Quarterly 7(4), 47-83.

[26] Wong, Timothy Ka-ying, Hsin-Huang M. Hsiao and Po-san Wan. (2009). "Comparing Political Trust in Hong Kong and Taiwan: Levels, Determinants, and Implications." Japanese Journal of Political Science 10(2), 147174.

[27] Wong, Po-san Wan, Hsin-Huang M. Hsiao. (2011). "The bases of political trust in six Asian societies: Institutional and cultural explanations compared." International Political Science Review 32(3), 263-281. 


\section{Hsiu-Wen Yang}

[28] Yang, Hsiu-Wen and Chih-Cheng Meng. (2015). "Exploring the influence of institutional approach on political trust with a multi-level model: Empirical analysis of 11 Asian countries." Paper presented at the 6th semipresidentialism \& democracy conference (May 16). 